\title{
Technetium Tc-99m Albumin Aggregated
}

National Cancer Institute

\section{Source}

National Cancer Institute. Technetium Tc-99m Albumin Aggregated. NCI Thesaurus.

Code C87398.

An injectable radiopharmaceutical formulation containing human serum albumin (HSA)

labeled with technetium-99m (Tc99m) in macroaggregates (MAA) with diagnostic

imaging activity. Technetium Tc 99m-labeled macroagg regated albumin contains the gamma-emitting Tc99m, a metastable nuclide of molybdenum-99. Upon injection into the hepatic artery and upon SPECT (Single Photon Emission Computed Tomography) imaging, distribution patterns and possible prediction of expected distribution of agents with similar particle sizes within the liver can be assessed and may give a prediction about the tumor response upon administration of such agents. 